\title{
Conceptualizing Microfinance For Effective Smallholder Farming In Africa
}

Stephen Mago, Great Zimbabwe University, Zimbabwe Costa Hofisi, North-West University, South Africa

\begin{abstract}
Smallholder farmers in Africa desperately need pro-poor interventions to alleviate their poverty through self-sustenance. In Africa, poverty is more prevalent in rural areas, where the overwhelming majority (about 80\%) of Africa's population lives and about $72 \%$ are poor. Microfinance cannot have substantial impact on poverty until it significantly penetrates the rural areas where small-scale agricultural activities by smallholder farmers need financial support. This paper thus attempts to conceptualise microfinance for smallholder farming in Africa which is done from the integrated view as opposed to a minimalist view.
\end{abstract}

The integrated view was selected because it focuses on the provision of credit facilities plus related follow-up services such as training, whilst the minimalist view is concerned about giving credit only. The paper relied on literature review and digestion to conceptualise microfinance as a strategy for boosting smallholder agricultural production. Many rural farmers have no access to the traditional financial system. Therefore, basic financial services are essential for the management of their productive endeavors. This paper argues that microfinance plays a pivotal role in the commercialisation, not only of smallholder farming activities but also the successful implementation of agricultural ideas. Microfinance is one way of helping farmers to sharpen their agricultural ideas so as to promote rural economic development.

With this background it has become imperative to explore the commercialisation of rural agriculture so as to empower the farmers. The financial sector in most countries does not cater for rural finance because they require physical collateral security that rural people do not have. In this article, micro-finance is seen to be a useful intervention that can be employed to economically empower the agricultural sector.

Keywords: Microfinance; Inter-Mediation; Smallholder Farming

\section{INTRODUCTION}

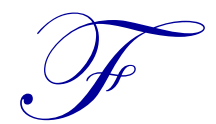

or four decades, Africa has received billions of dollars in foreign aid, but underdevelopment still persists. Poverty is more prevalent in rural areas where the overwhelming majority (about $80 \%$ ) of Africa's population lives and about $72 \%$ are poor. African smallholder farmers have failed to improve productivity for the enhancement of their livelihoods. As such, they face poor agricultural productivity due to lack of finance and other essential inputs. It remains a puzzle why Africa is still ridden with poverty, yet natural resources, such as diamonds, oil, gold and other base metals, good agricultural soils, tourism potential, and human resources, are abundant.

The ability by smallholder farmers to access financial services is regarded as one of the many strategies that are meant to help increase their income and productivity with the ultimate aim of reducing poverty. Microfinance services involve the provision of micro-credit, establishment of micro-savings, micro-insurance, micro-housing, micro-green finance and village banking. The greater populace in the rural areas lacks access to productive capital for their smallholder farm activities. Rural agricultural activities are hampered by lack of agricultural inputs; that is, active poor farmers lack access to inputs and, as such, they are exposed to risks. Such risks culminate in poor 
harvests, health problems and localized socio-economic crisis. Additionally, rural areas are poorly integrated to the markets; hence, smallholder farmers become hostages of middlemen who come with provisions, agricultural inputs and domestic utensils for forward arrangements. Such arrangements are done during the planting season for the exchange of their output after the harvest. Unfortunately, the crops are taken by middlemen at duplicitous prices since they have no access to the market for better prices. In extreme circumstances, some smallholder farmers lose their pieces of land to moneylenders. Adams et al (1984:13) state that, "Stories about poor farmers who lose their land to evil moneylenders are retold ..." Consequently, poor farmers' livelihood strategies are distorted when their land is taken away from them. Such arrangements can be avoided if rural financial intermediation is developed. Moreover, small-scale farmers are duped of their precious assets by informal lenders who exploit them to enter into interlocked contracts. Due to lack of access to banks, poor people have fallen prey to private money-lenders who are known as "loan sharks" because of their exploitative tendencies. Smallholder farmers in Africa desperately need pro-poor interventions so as to help the poor farmers escape poverty through self-sustenance. Thus, this study focuses on smallholder microfinance which has gained currency as one of the interventions that can be used to support smallholder farming. However, microfinance cannot have an impact on poverty until it significantly penetrates the rural areas where small-scale agricultural activities need financial support.

One of the main reasons why smallholder farmers have been failing is largely because they tend to operate along the lines of peasantry agriculture instead of running along commercial lines. Commercialisation involves operating at profit for sustainability. This is attributable to the minimalist approach focusing on provision of agricultural financial services instead of the integrated approach. While the former emphasizes the provision of credit only, the latter argues for financial and nonfinancial support services. Non-financial services include training, social intermediation, enterprise developmental services and social services.

This paper utilises an integrated approach to the provision of microfinance to smallholder farmers and other vulnerable groups of society. The researchers are of the view that governments should give special attention to these people who are excluded, yet they are economically active and their business efforts show that they have entrepreneurial traits that need to be developed so as to realize economic growth from the grassroots. The contributions of smallholder farmers will go a long way in realizing economic growth in rural economies. The most vulnerable population groups (the rural populace) facing situations of poverty, quasi poverty or abject poverty, could use microfinance to develop income-generating activities that are potentially powerful to lift them out from poverty's "slippery slope". Besides poverty reduction, microfinance can also help African countries to reduce welfare assistance (that includes aid from international donors) and promote economic entrepreneurship, especially among young people. The problem with aid is that it is addictive and creates a donor syndrome and does not promote innovation for sustainability. What Africa needs is the development of sustainopreneurship (a new concept developed by Anders Abrahamsson, 2007) in the most simplified form, described as entrepreneurship and innovation for sustainability. The paper explores the microfinance concept and draws lessons from the East which will be used to promote commercialisation of agricultural ideas by smallholder farmers.

Smallholder famers in Africa suffer from lack of financial intermediation, social intermediation, enterprise developmental services and social services, coupled with the fact that they do not have support from the traditional financial sector. This has led to a dependency syndrome resulting from government hand-outs, subsidised credit and donor assistance. These approaches have largely been informed by the minimalist approach to the provision of credit which involves providing financial intermediation only. Organisations pursuing the minimalist approach occasionally offer limited social intermediation services to facilitate group formation, leadership training and cooperative learning. The minimalist approach is based on the premise of a single "missing piece" in enterprise development (Ledgerwood, 1999:66). The proponents of this approach argue that it offers cost advantages for MFIs and also allows them to remain focused.

In contrast, the integrated approach calls for the provision of financial intermediation, social intermediation, enterprise developmental services and social services. The approach views the client from a holistic perspective which looks attractive and convincing. The approach is based on the premise that enterprise growth requires a whole range of services as previously mentioned. This approach's holistic stance gives the clients a complete package that has the capacity to make them realize their full potential; hence, it was adopted in this research. 
The paper hopes to influence interventions by microfinance stakeholders that include microfinance practitioners, development specialists, donors, non-governmental organizations (NGOs), bankers, government officials and smallholder farmers by advocating an integrated approach to microfinance. Experiences from the East are highlighted because of their success and possible replication in Africa in the smallholder farming sector. The following questions emerge from this synopsis:

1. How can smallholder farmers be weaned from their dependency syndrome?

2. Does rural microfinance work for smallholder farmers?

3. Which commercial ideas can be exploited by smallholder farmers?

4. What are the challenges and opportunities for smallholder farmers in Africa?

5. What lessons can smallholder farmers in Africa learn from the East's experiences in microfinance?

It is on the basis of these questions that the following objectives of the paper were identified, examining how provision of micro financial services can contribute towards commercialization of smallholder farming activities, identifying challenges faced by the smallholder farmers, and investigating the possible opportunities that can be exploited by smallholder farmers to move out of dependency.

\section{Conceptual Issues}

The concept of microfinance is "marked by a major debate between two leading views on how to fill the 'absurd gap' in microfinance (Robinson 2001:41). " The two views are the financial system approach and the poverty lending approach." The two theoretical perspectives posit that financial services should be made available to the poor people who are always marginalised. Such inclusive approaches will also take care of smallholder farmers. According to Robinson (2001:7), "the poverty lending approach focuses on reducing poverty through credit and other services provided by institutions that are funded by donor and government subsidies and other concessional funds. The primary goal is to reach the poor, especially the poorest of the poor, with credit".

This paper advocates a possible compromise between the two approaches. While the poverty lending approach's (PLA) emphasis is on the provision of micro-credit (Robinson, 2001:8), the financial systems approach (FLA) is concerned about commercial intermediation for smallholder farmers. It argues for institutional sustainability. Microfinance institutions (MFIs) provide loans to the economically active poor at a reasonable cost. For smallholder farmers, this will have an effect of ensuring an uninterrupted supply of agricultural inputs. According to Robinson (2001:8), "commercial microfinance is not appropriate for extremely poor people who are badly malnourished, ill, and without skills or employment opportunities." Research has noted that if borrowers are starving, they are tempted to use the loans received to purchase food items for their families.

\section{What Is Microfinance?}

Robinson (2001) defines microfinance as "small-scale financial services-primarily credit and savingsprovided to people who farm or fish or herd; who operate small enterprises or micro-enterprises where goods are produced, recycled, repaired, or sold; who provide services; who work for wages or commissions; who gain income from renting out small amounts of land, vehicles, draft animals, or machinery and tools; and to other individuals and groups at the local levels of developing countries, both rural and urban”(Robinson, 2001:9).

Ledgerwood (1999), Chavan and Ramakumar (2002), IFAD (2004), Armendariz de Aghion, and Morduch (2005) and Kondo et al. (2008) conceptualize microfinance in the same vein. The definition by Robinson implies that the poor have no access to loans, thus microfinance attempts to ensure that their economic activities receive finance. Lack of finance leaves smallholder farmers vulnerable to many external forces, including drought.

"Microfinance" and "micro-credit" are often used interchangeably. "However, the two concepts have different resonances. Microfinance (which entails financial inclusion) is wider than microcredit (which sees credit as the only missing piece). Borrowing from Grameen Bank, Chavan and Ramakumar (2002:956) define microcredit as "small loans extended to the poor for undertaking self-employment projects that would generate income and enable them to provide themselves and their families". 
The above definitions share a common position about microfinance being the provision of small loans to the poor for them to manage their precarious lives. However, it is important to note that some use microfinance and micro-credit interchangeably, yet the latter refers to the offering of small loans only whilst the former refers to the provision of a combination of follow-up (both financial and non-financial services) for smallholder farmers.

The micro-finance intervention dates back to the 1970s when Professor of economics (Muhammad Yunus) of Bangladesh started giving out small loans to villagers in the locality and initiated the Grameen Model. This model has received resounding results that have seen the poor (case of Bangladesh) benefiting from micro-finance. The efforts led to the establishment of the Grameen (whose name means 'rural' in Bengali) Bank.

The "Grameen Bank, which was founded in 1976 as a project and transformed into a specialized bank in 1983 and is the best-known micro-credit program. By 1994, it had mobilized more than two million members - 94 percent of them women - and achieved a loan recovery rate of more than 95 percent (Khandker, 1998). In countries as diverse as Bangladesh, Benin and Dominica, repayment rates are as high as 97 percent” (IFAD, 2004:1)

\section{Why Microfinance?}

Microfinance is one way of enhancing smallholder farming. It facilitates the availability of credit, savings and other services such as micro-insurance, micro-housing, micro-tourism, and micro-green. Microfinance helps smallholder farmers obtain small loans for the lubrication of their agricultural activities. Microfinance is ideal for poor farmers since they have a good repayment culture. Research findings show that an average repayment rate of $80 \%$ has been achieved among poor borrowers in Bangladesh, the Philippines and Brazil (Armendariz de Aghion and Morduch, 2005; Kondo et al., 2008). Microfinance institutions, such as credit unions, government agencies and non-governmental organizations, provide smallholder farmers with small loans and boost their agricultural activities through procurement of inputs and payment of wages (IFAD, 2004).

The need for microfinance is motivated by weak financial systems that are prevalent in most African countries. For example, the World Bank cited "Kenya, Mauritius and South Africa as exceptions" (World Bank, 2004:8). Research findings show that few African adults (about 20\%) have "an account with a formal or semiformal financial intermediary" (Honohan and Beck, 2007:139). This is also true for savings and payments, as it is for credit and lending. The World Bank reports of 2000/2001 and 2004 further show that 'underbanking' in Africa is very high (World Bank. 2001, 2004). 'Underbanking' has a crippling effect on economic development through low savings. In the agricultural sector, lack of agricultural finance cripples agricultural productivity. Levine (1997) outlines the importance of Financial Systems Deepening (FSD) as an important ingredient of overall economic development. FSD involves the mobilization of financial savings, management of financial risks, access to information about investment opportunities, borrower monitoring (control systems) and facilitating trade. Microfinance could be used as a conduit for the development of FSD in the rural areas. Inclusive finance is the agenda of microfinance, thus the poor become part of the economically active population. Empirical evidence helps to shed more light on the impact of microfinance as a development tool among poor people, especially smallholder farmers.

Microfinance development represents financial sector development (FSD) that has a potential of supporting those excluded by the financial system in an economy. FSD enhances access to financial resources by the poor. According to DFID (2004), FSD involves financial risk management and savings mobilization. It also involves acquiring information on investment opportunities and monitoring of borrowers. Financial inclusion is promoted by a combination of these elements. Levine (1997) argues that inclusive finance ultimately leads to economic growth and development, thus reducing poverty. FSD reduces poverty directly and indirectly. Direct poverty reduction is achieved through income increases while indirect poverty reduction is achieved through its impact on economic growth that will have spillover effects on poverty.

The DFID argues that smallholder farmers and the poor can have full economic participation once they have access to finance. Access to finance removes the constraints that inhibit them to improve their productive endeavours. 


\section{Lessons From International Experiences}

The Grameen model is a spectacular success story that was started by Muhammad Yunus (1976) in Bangladesh (Kandker, 1998, Karmakar, 1999, Robinson, 2001; Armendariz de Aghion and Morduch, 2005). The Grameen case used the group lending methodology as a way of delivering microfinance to the poor people. The poor do not have physical collateral security; hence, the model advocates for what it called "social collateral" which involves peer pressure execution by group members. That is, individual borrowers use a self-selection mechanism to form borrowers' groups. Group members take responsibility for each member's loan using peer pressure (Kota, 2007; Karmakar, 1999; Armendariz de Aghion, 2005). Enforcement to make repayments is done through peer pressure to guarantee repayment. As such, a question that emerges is, "do people repay because of pressure or they are willing or able to repay?" Success has also been recorded in other parts of India, Bangladesh's BRAC, China, Indonesia, etc. in the Asiatic countries and Uganda, Tanzania, Malawi and Kenya, among other African countries. The concept of sustainability with regards to rural financed projects and Microfinance Institutions (MFIs) will be given attention so as to get a lasting solution to the problem of rural poverty.

Although this concept succeeded in many countries, it is important to note that it had negative effects in some parts of the world. For example, in the Indian province of Andhra Pradesh, "the microfinance crisis in India... broke out in fall 2010" (Arunachalam, 2011:1). Analysts, such as Sharma (2011), argue that we can classify it as a once-off problem.

\section{Bangladesh Rural Advancement Committee (Brac)}

BRAC's strategy involved the target group approach. Training courses were provided to promote literacy, awareness of causes and nature of poverty, raising self-confidence, and to make the poor cognizant of their potentials. The organization extends credit after twelve months of training which may seem like a long waiting period, but it answers the question of sustainability.

\section{Approaches To Rural Microfinance}

It is important to develop services that are both responsive to the clients' needs and is financially sustainable. The term client is used because it should be a commercial and not a welfare-oriented venture. It is important at this juncture to highlight the risks that are associated with microfinance. The providers of microfinancial services debate on whether to use the minimalist or integrated approach in financial intermediation. The approach is based on the premise of a single "missing piece" in enterprise development (Ledgerwood, 1999:66). The proponents of this approach argue that it offers cost advantages for MFIs and also allows them to remain focused.

The integrated approach calls for the provision of financial intermediation, social intermediation, enterprise developmental services and social services. It argues that enterprise growth requires a whole range of services as previously mentioned. This approach's holistic stance gives the clients a complete package that has the capability of making them realize their full potential. However, Legderwood (1999) cautions that any MFI that chooses to adopt the approach has to take care of the following potential issues:

1. Providing financial and non-financial services are two distinct activities, which may have conflicting objectives.

2. It is often difficult for clients to differentiate "social services", which are usually free from "financial services" which must be paid for.

3. MFIs offering other services may have difficulties identifying and controlling the cost per service.

4. Non-financial services are rarely financially sustainable" (Ledgerwood, 1999:66).

Therefore, we argue that MFIs can enter into strategic partnerships with other organizations such as the government, donors and NGOs (Non-Governmental Organizations), and adopt the minimalist approach. This can be effective in providing financial and social services for the sustainability of smallholder farming activities. It is imperative that African governments work with the providers of microfinance for the success of smallholder farmers. 


\section{Microfinance And Smallholder Agriculture}

The World Bank (2011:1) observes that "Agriculture accounts for 17\% of the African region's GDP, 40percent of exports and a substantial share of employment". The World Bank further opines that in sub-Saharan Africa, increasing crop production by $1 \%$ translates to a $0.7 \%$ fall in the number of people in poverty. This represents a higher percentage than the $0.5 \%$ fall experienced in East and South Asia. In Latin America, the increase in crop production by $1 \%$ leads to $0.1 \%$ reduction in poor people. This report shows the importance of smallholder farming in Africa. Therefore, African governments need to develop roads, electrification, and communication facilities that will connect the smallholder farmers to the markets, since rural areas are poorly integrated to the markets.

Smallholder farmers' support could be the way forward since their contribution to poverty reduction and food security is significant. According to Matshe (2009), " $50 \%$ of the world's hungry are smallholder farmers." Such statistics compel us to advocate for smallholder farming support. As statistics reveal, such support will definitely have an impact on poverty reduction and food security. With contemporary challenges of climate change and global warming, food insecurity is a threat to humanity.

A holistic approach is required to achieve the full benefits of smallholder farming. A full package of resources should be given to the smallholder farmers so as to empower their productive efforts. These include natural capital (land), human capital (knowledge, skills, labour; financial capital) microfinance; and social capital (networks, synergies and alliances) and Physical Capital, infrastructure (roads, telecommunication facilities, electricity and buildings). Human capital is responsible for employing the other resources to produce commodities. Nevertheless, human capital needs to be developed in order to capacitate it to employ the other production factors. Capacity building is thus required through training and provision of other non-financial services, as illustrated in the integrated approach to microfinance. Financial resources should also be availed to work, as a lubricant to production; that is, there is need for them to be financially liquid. Therefore, microfinance advocates for training the recipients of credit so that they know how to efficiently and effectively manage financial resources.

We need to underline the fact that smallholder farmers are vulnerable to a number of negative conditions. The factors that affect smallholder farmers, in general, are highly interrelated, making them complex. Such conditions include natural disasters, political and economic shocks, social shocks, and other related disturbances. The FAO states that "while their (smallholder farmers) livelihood strategies are designed to better prepare for and cope with such shocks, their limited access to the five forms of capital described above impede their opportunities for rapid and effective response" (FAO, 2006:8). Access to financial resources is pivotal, not only for the commercialisation of smallholder farming activities but to all the other factors that may affect land holders. Vincent (2004:2) explains that as "financial services help the poor expand their economic activities and increase their incomes and assets, their self-confidence grows simultaneously". Self-confidence and dignity are some of the nonmonetary benefits that can be tapped from microfinance.

\section{A Synopsis Of African Experiences}

Research findings show that the demand for microfinance is very high in Africa. As such, rural microfinance is being developed in a number of countries in Africa. Providers of microfinance include government (in form of subsidized credit), private institutions, informal organizations, NGOs (non-governmental organizations), friends and relatives. In response to high demand for capital by smallholder farmers and other unbanked groups, organizations such as credit unions, community-based organizations, rural banks, financial cooperatives and savings societies have emerged.

In Zimbabwe, the government initiated the "Maguta Programme" in 2007 which was established to give agricultural inputs in support of smallholder farming. Under the Maguta programme (Maguta is a Shona term meaning 'feeding the nation'), smallholder farmers were given subsidized inputs. However, the government did not provide any follow-up services, so a number of smallholder agricultural activities failed to take-off. Drought also contributed towards the failure of the programme since the farmers were not empowered to be innovative in drought-mitigating strategies. With the commercialisation of agricultural ideas, the farmers with productive capital can start irrigation projects so as to reduce drought effects. 
Kenya also has one of the most developed microfinance sectors. A spectacular example is the Kenya Rural Finance Enterprise Programme (K-REP) which started as a replication of the Grameen model. It started as “... an intermediary organization in 1984 providing funds to NGOs for on-lending to microenterprises and expanded to work on USAID's Private Enterprise Development Project in 1987” (Mixmarket, 2011:1).

Currently, it is a well-established bank that provides microfinance based loans, personal banking and business banking services. Microfinance loans are group-based and are loan-designed for operators of microenterprise and smallholder farmers. Most micro-enterprises and smallholder farmers do not have conventional collateral such that they fail to access loans from traditional financial institutions. K-REP promotes financial inclusion by making sure that the micro-enterprise operators and smallholder farmers get loans to prop up their business activities. The success of K-REP motivated the establishment of other microfinance institutions such as the CAREWEDCO, Women Finance Trust, and Faula. However, in Kenya, K-REP remains the best provider of finance to the poor.

\section{CONCLUSION AND POLICY RECOMMENDATIONS}

Smallholder farmers tend to be marginalised by traditional financial institutions. The farmers need to be part and parcel of the financial mainstream. Since their productive contribution is significant, access to finance will enable them to maximise their local socio-economic opportunities. It is clear that provision of microfinance to smallholder farmers will encourage innovative commercial ideas. Smallholder farmers are full of potential because they have the willingness and ability to engage in productive farming activities. Their greatest advantage is that they are economically active but, on the other hand, their obstacle is lack of access to finance. Available productive opportunities need to be tapped through the provision of finance. Improved financial access by smallholder farmers is expected to bring in positive impact on their productivity positively. The use of local resources, such as land, labour, natural resources and social capital, could be strengthened by providing microfinance to this category of farmers.

What is equally important is to develop the capacity of the farmers for them to be innovative. Innovativeness is, in the majority of cases, supressed by free financial hand-outs. We are therefore not advocating giving donations to farmers but, rather, giving them affordable loans that will also encourage them to work harder. Innovative ideas can also be developed as they work towards the goal of increasing their productivity for increased benefits. Financial deepening, as proposed by Levine (1997), could be the answer.

This paper proposes replicating the Grameen Bank model which has done relatively well in a number of countries. For example, the model is still running in Bangladesh (BRAC and Grameen Bank), Brazil (BancoSol), Kenya (K-REP) and Zimbabwe (Credit Against Poverty). However, the model requires to be attuned to the local environments. K-REP's success story beams a ray of hope that microfinance can work in Africa to empower poor farmers and even low income groups and the unemployed.

An integrated approach, however, could be adopted. Lending that is coupled with strategic alliances by different organisations is also recommended. However, a minimalist approach to lending works when the MFI is growing, since the integrated approach demands a lot of effort, time and financial resources. Moreover, it is generally expensive to run an integrated lending programme.

The microfinance industry needs support from the governments so as to promote the livelihoods and growth of smallholder farmers. Development of a supportive regulatory framework will also help in this regard. Repressive policies should be avoided so as to promote the growth of the microfinance sector in Africa. For example, the Grameen model is guided by rules and regulations that are different from those guiding traditional banks. The Grameen Bank of Bangladesh is owned by borrowers (they have a stake of 94.34\%) and the Bangladesh government controls a minority stake of $5.66 \%$. 


\section{AUTHOR INFORMATION}

Stephen Mago is currently a Lecturer and MBA Lead Specialist in the Faculty of Commerce, Department of Accounting \& Information Systems at Great Zimbabwe University. His areas of expertise include microfinance, development finance, entrepreneurship, local economic development, co-operatives, and research methodology. Email: stepmago@gmail.com.

Costa Hofisi is a Senior lecturer in the Department of Public Administration at North-West University in South Africa. His research interests include public finance, public policy, and development management. E-mail: costa.hofisi@nwu.ac.za (Corresponding author).

\section{REFERENCES}

1. Abrahamsson, A. (2007). Sustainopreneurship - Business with a Cause: Conceptualizing Entrepreneurship for Sustainability. Retrieved from http://www.uppsatser.se/om/Anders+Abrahamsson/.

2. Adams, D. W., Douglas, H. G., and von Pischke, J. D., eds. (1984). Undermining Rural Development with Cheap Credit. Boulder, CO: Westview Press.

3. Armendariz de Aghion, B. and Morduch, J. (2005). The Economics of Microfinance. London: Massachusetts Institute of Technology.

4. Arunachalam, R. S. (2011). The Journey of Indian Micro-Finance: Lessons for the Future. Chennai: Aapti Publications.

5. Chava, P. and Ramakumar, R. (2002). Micro-credit and rural Poverty; An analysis of Empirical Evidence, Economic and Political Weekly Retrieved from http://www.yorku.ca/hdrnet.

6. DFID (Department for International Development). (2004). The Importance of Financial Sector Development for Growth and Poverty Reduction. Policy Division Working Paper. (Retrieved from http://www.ruralfinance.org/fileadmin/templates/rflc/documents/DFID_finsecworkingpaper.pdf.

7. FAO. (2006). Food and Agriculture Organisation. 2006. Food and Agriculture Organisation's Contribution to Good Policies and Practices in Agrarian Reform and Rural Development: A Brief Overview, International Conference on Agrarian Reform and Rural Development, 7-10 March 2006, Retrieved from http://scholar.google.com/scholar?q=Land+reform+and+microfinance+in+Brazil\&hl=en\&um=1\&ie=UTF$8 \&$ oi $=$ scholar.

8. Honohan, P. and Beck, T. (2007). Making Finance Work for Africa, World Bank, Washington D.C. USA.

9. International Fund for Agriculture and Development. (2004). Microfinance: Macro-benefits. Italy: IFAD. www.ifad.org/ruralfinance. (accessed 15 September, 2007).

10. Karmakar, K. G. (1999). Rural Credit and Self-help Groups: Micro-finance Needs and Concepts in India. New Delhi: Sage Publications.

11. Khandker, R. S. (1998). Fighting Poverty with Micro-credit: Experience in Bangladesh, Oxford University: World Bank, USA.

12. Kondo, T. A., Orbeta Jr, Dingcong C., and Infantado, C. (2008). Impact of Microfinance on Rural Households in the Philippines. IDS Bulletin Volume 39 Number 1 March 2008. Institute of Development Studies.

13. Kota, I. (2007). Back to Basics - Microfinance: Banking for the Poor, Finance \& Development - A quarterly magazine of the IMF http://www.imf.org/external/pubs/ft/fandd/2007/09/index.html. (Retrieved September 25 2007).

14. Ledgerwood, J. (1999). Microfinance Handbook: an institutional and financial perspective (Sustainable banking for the poor). Washington D.C., USA: The World Bank.

15. Levine, R. (1997). 'Financial Development and Economic Growth: Views and Agenda'. Journal of Economic Literature Vol. XXXV 688-726.

16. Matshe, I. (2009). Boosting smallholder production for food security: some approaches and evidence from studies in sub-Saharan Africa. Agrekon, Vol 48 (4).

17. Mixmarket (2011). K-Rep Bank. (Retrieved from http://www.mixmarket.org/mfi/k-rep\#ixzz2AylQmwbl.

18. Robinson, S. M. (2001).The Microfinance Revolution, Washington, D.C: The World Bank.

19. Sharma, K. E. (2011). Andhra Pradesh is a one-off problem: SKS Microfinance. (Retrieved fromhttp://businesstoday.intoday.in/story/andhra-pradesh-sks-microfinance-vikram-akula/1/15705.html. 
20. Vincent, G. (2004). Sustainable Microentrepreneurship: The Roles of Microfinance, Entrepreneurship and Sustainability. Retrieved from www.gdrc.org/icm/micro/guy sust-micro.pdf in Reducing Poverty in Developing Countries.

21. World Bank (2001). World Development Report 2000/2001. Attacking Poverty. New York: Oxford University Press.

22. World Bank (2004). "Kenya Investment Climate Assessment: Enhancing the Competitiveness of Kenya's Manufacturing Sector: The Role of the Investment Climate." Washington, DC: World Bank.

23. World Bank (2011). Sub-Saharan Africa Region. Global Economic Prospects June 2012, Sub-Saharan Africa Retrieved from http://siteresources.worldbank.org/927C20F1-4B09. 


\section{NOTES}

